SHS Web of Conferences 17, 01020 (2015)

DOI: $10.1051 /$ shsconf/20151701020

(C) Owned by the authors, published by EDP Sciences, 2015

\title{
Teaching Design of Property Valuation Practice Course in Vocational College
}

\author{
Kecheng Li, Juanjuan Wen, Li Quan \\ Chongqing Jianzhu College, Chongqing, 400072, China
}

\begin{abstract}
In the professional curriculum system of real estate management and valuation in vocational college, in view of the students who graduate employment for the vocational of real estate assessor, we set the curriculum of property valuation practice. So we shall in accordance with the required work capacity of real estate assessor to carry out the teaching design and implementation of teaching, to reach the goal of setting this course. After analysis of vocational ability, teaching target location, determination of teaching content, planning teaching process, we completed teaching design of property valuation practice course, and implement teaching according to teaching design, obtain good teaching effect.
\end{abstract}

Keywords. teaching design; property valuation; practice course; vocational college

\section{Introduction}

In "Vocational college Teaching Standards of The Ministry of Education - Professional Teaching Standards of Estate Management and Appraisal" and "Professional Teaching Basic Requirements of Real Estate Management and Appraisal in The Higher Vocational Education", the goals of training personnel for the real estate business and assessment is to training technology skilled talents adapt to the real estate development, operation, management and service. The initial jobs include real estate assessor ${ }^{[1][2]}$.

Therefore, the professional course system of real estate management and assessment in high vocational schools, aimed at students graduate employment for the vocational of real estate assessor, set property valuation practice curriculum. Because professional students graduate from the real estate business and assessment of vocational college, recruit to property valuation institutions, only for the vocational of real estate assessor, and therefore we must to cultivate students with real estate assessor vocational capacity as the goal, to carry on teaching design and implementation of the property valuation practice course.

"The Regulation of Urban Real Estate Intermediary Services" revised and promulgated by the original ministry of construction under the state council stipulate, practice a system of real estate price evaluation personnel qualifications, real estate price evaluation personnel is divided into real estate appraiser and real estate assessor. Real estate appraiser examination was formulated by the construction administrative departments and the personnel administrative department under the state council. Real estate assessor exam method formulated by the construction administration of the people's government and the provincial and municipal real estate management authority. ${ }^{[3]}$ Thus, real estate appraiser vocational ability and real estate assessor capacity, it is not the same. 
Real estate appraiser examination method jointly formulated by the construction administrative and the personnel competent department under the state council, and be explicitly stipulated standards of real estate appraisers vocational ability.

Unfortunately, the people's governments construction administrative authority or real estate administration authority at all levels, almost hadn't formulate real estate assessor exam measures, also does not have a real estate assessor qualification certification system. Therefore, vocational college lack of authority to take real estate assessor vocational ability as the goal, and to carry on the property valuation practice course teaching design and teaching. If put the real estate appraiser vocational ability as the goal, to take practice curriculum teaching design and teaching of property valuation of vocational college, obviously not suitable for vocational college students' cognitive and learning capacity, also far from the professional talent training goal on vocational college of real estate business and appraise.

Because of this, we further thorough investigate from the property valuation institutions, according to the practice in the property valuation institutions for many years, and teaching experience in vocational college, after a detailed analysis of the real estate assessor vocational ability, to locate the property valuation practice curriculum teaching goal, determine the teaching content, plan teaching process, and carry out teaching in accordance with the teaching design, complete teaching goal of improve students' vocational ability to real estate assessor.

\section{Analyze vocational ability}

Analysis of real estate assessor vocational ability must be from property valuation procedure, real estate assessor to undertake work in property valuation program content.

\subsection{Analyses on appraisal of real estate}

Property valuation is an activity. Which the valuation professionals in line with the appraisal purpose, abide by the principles of valuation, according to the valuation process, select appropriate valuation methods, and on the basis of comprehensive analysis of affecting real estate prices, estimate and determine the real estate objective and reasonable price or value in point of valuation. In accordance with the laws and government regulations in China, Chinese property valuation is divided into policy valuation and market valuation, and shall entrust professional appraisal institutions with the property valuation qualification certificate to conduct (here in after referred to as the property valuation institution). After accepting a commission, property valuation institutions appointed certified real estate appraisers, certified land appraisers and real estate assessor, according to the "Property valuation Standard" (GB/T50291-1999), "Urban Land Appraisal Regulations" (GB/T 18508-2001), evaluate commissioned property (that is, the appraisal object) "independent, objective and fair".

On the basis of the above two national standards, complete property valuation program by twelve steps: (1) accept valuation commissioned; (2) explicit appraisal basic matters; (3) estimate work plan; (4) collect information required for estimation; (5) field survey evaluation object; (6) analyze appraisal object and real estate market, (7) select valuation methods for measuring; (8) determine the appraisal results; (9) write appraisal report; (10) internal audit appraisal report; (11) issue valuation report; (12) valuation data archiving ${ }^{[4][5]}$.

\subsection{Analysis of vocational working content}

No.151 decree of the "regulation of certified real estate appraiser" promulgated by the ministry of construction under the state council ruled, after the ministry of construction and personnel unified exam, personnel who obtain real estate appraiser qualification, employed at a property valuation institutions, can engage in property valuation practice after register ${ }^{[6]}$. The "land appraiser qualification examination regulation" revised in 2010 by the ministry of land and resources under 
the state council, ruled that passed national qualification exam for land appraiser, may obtain the status of land appraiser. Acquire the land appraiser's qualification and in the practice of land valuation institution appraiser, should through practice examination and practice registration. The practice registration land appraiser will sign the land valuation report, and take legal responsibility [7].

The two government regulations expressly stipulated, registered real estate appraiser and land appraiser (hereinafter generally referred to as the certified real estate appraiser) appraise independently real estate, sign the property valuation report, take property valuation legal responsibility. Therefore, real estate assessor has no qualification to engage independently in property valuation activities, sign property valuation report, take property valuation legal responsibility, only under the guidance of certified real estate appraiser, supporting in the process of property valuation, assist certified real estate appraiser to complete the property valuation project.

The process of property valuation, real estate assessor do auxiliary work under the guidance of certified real estate appraiser as below:

(1) According to certified real estate appraiser instructions to collect the ownership data of property valuation object, prepare required basic character and basic data for estimation.

(2) Led by the registered real estate appraiser, field reconnaissance appraisal object, and take pictures of the valuation object from inner, appearance and around. Fill in the appraisal object survey form, full records the actual status of the appraisal object in valuation point.

(3) According to the basic data and calculation methods chose by certified real estate appraisers to measure property valuation parameters. We according to the evaluation parameters and calculation formula selected by registered real estate appraiser to calculate property valuation result.

(4) According to the main points or outline formulated by the registered real estate appraiser to draft the property valuation report. In accordance with the opinion of the certified real estate appraiser, we modify the first draft of the property valuation report. And then deliver to certified real estate appraisers to amend property valuation report.

(5) Print the property valuation report revised by certified real estate appraiser, settle property valuation report attachments orderly. We photocopying, binding property valuation report and accessories in accordance with the relevant provisions, then submit to certified real estate appraiser for signing and submit to the property valuation institutions for sealing, and deliver property valuation project principal.

(6) We collect, sort out the ownership data, basic character and basic data, the measuring data of property valuation parameter, the calculated data of property valuation result, the property valuation report, the property valuation report accessories, then bind those after the examination and approval by certified real estate appraiser. Finally transfer to archives management department of property valuation institutions on file for future reference.

\section{Locate the target of course teaching}

The analysis of the work content of real estate assessor, shows that the real estate assessor vocational ability include six aspects: (1) the ability of collecting property valuation information; (2) the ability of survey property valuation object; (3) the ability of calculate property valuation, (4) the ability of drafting property valuation report; (5) the ability of making property valuation report; (6) the ability of organize property valuation files.

Property valuation practice course, should train students to master the six work ability as the goal to teaching design. To be specific, the property valuation practice teaching goals should be located in the following six aspects, namely:

(1)To cultivate students' ability of collecting data of property valuation

(2)To cultivate students' ability of surveying property valuation object

(3) To cultivate students' ability of calculating property valuation 
(4)To cultivate students' ability of draft the property valuation report

(5)To cultivate students' ability of making property valuation report

(6)To cultivate students' ability of organizing the property valuation files

Teaching content should be adapted to the teaching goal, and in accordance with principle "based on application, main to practical, degree for the sufficient". In accordance with the requirements for both, the identified property valuation practice teaching content includes two parts.

First part is the basic theory of property valuation, including: (1) the concept of property valuation; (2) the demand of the property valuation; (3) the element of property valuation; (4) the principle of property valuation; (5) the procedures of the property valuation; (6) the influencing factors of real estate value.

Second part is the property valuation basic skills, including:

(1)The scope and requirements of collecting property valuation information

(2)The content and requirements of investigating property valuation object;

(3) The method and formula of calculating property valuation;

(1) market comparison method

(2) income reduction method

(3) cost approach method

(4) hypothetical development method

(5) benchmark land price method

(6) long-term trend method

(4) The format and specification of the property valuation report

(5) The content and requirements of property valuation archives

\section{Plan the process of course teaching}

According to the vocational college students' cognitive level and learning ability as well as integrative teaching mode of "teaching, learning and doing", divided the process of property valuation practice teaching into six teaching links which are basic theory teaching, visit the valuation institutions, basic skill teaching, case seminar, property valuation simulation training, curriculum evaluation.

\subsection{Basic theory teaching}

We use classroom teaching method in the basic theory teaching. Teachers in the classroom, explain the concept, demand, elements, principle, procedure and value influence factors of property valuation in detail, then arrange the homework. Students through lectures and assignments lay a solid foundation of property valuation basic skills.

\subsection{Visit the valuation institutions}

After the basic theory of teaching, teachers lead students to visit the property valuation institutions. Its purpose is to make them understand the management mode of property valuation institutions in the site, feel the workplace atmosphere of property valuation institutions, watch the common resources for property valuation, property valuation report, property valuation archives. To increase students' understanding of the property valuation and further arouse the enthusiasm of students to learning property valuation practice curriculum.

\subsection{Basic skill teaching}


Basic skill teaching still use the way of lectures and finish the homework. Teachers in classroom use case teaching actively, avoid tedious calculation formula. Especially use case in detail to teach different applicable objects, the suitable scope and applicable conditions of income method, market comparison method, cost approach method, hypothetical development method, benchmark land price method and long-term trend method. And homework associated with lecture content, when students finish the homework, grasp to use various property valuation methods.

\subsection{Case seminar}

After the basic skill teaching, engage senior certified real estate appraiser to hold property valuation case seminar for the students is necessary. Senior certified real estate appraiser should select cases which possess factualism, typicality, novelty.

Factualism refers to that the examples in the lecture are personally involved in property valuation project. Typicality means, examples in the lecture contains more special and complex professional problem, which be solved by using professional experience and skills. Novelty means that the case in the lecture must be recently completed in property valuation project ${ }^{[8]}$.

Students have known the latest development of property valuation theory, practice, skills, experience, laws, regulations and policies from case seminar which have factualism, typicality, and novelty. And further deepen students' understanding of the basic theory and grasp the basic skills of property valuation.

\subsection{Simulation training}

Students are not experience about the property valuation links of lectures, visit the valuation institutions, the basic skills teaching and case seminar teaching. So it is necessary for property valuation simulation training. Through simulation training, the students try to use the basic theory and skills to carry on the property valuation, experience the whole process of the property valuation and consolidate the basic theory and skills.

Simulation training method is taking senior certified real estate appraiser as principal, teachers teaching as auxiliary, preparing property valuation simulation training commitments. Put the property valuation project completed by property valuation institution or teaching building, office building, school canteen, supermarkets, the shops around college campus and residential in the vocational college as property valuation object. Senior real estate appraiser guide students to use appropriate valuation methods, to simulate evaluate the hypothesis property valuation object, in accordance with the specifications to comply simulate property valuation report, then to make student evaluation of property valuation report.

\subsection{Curriculum evaluation}

After finish the five teaching, make the necessary review to student's study effect. There are two purposes to examination. One is urging students to comprehensive review, to summarize and consolidate the basic theory and skills what they have learned. The other is to test students' effect and course teaching effect.

Through the analysis of student assessment, we can found the problems in students' learning and the shortage of each teaching link in the whole teaching process. Those for teachers to sum up the experience of teaching, learn to carry forward the experience and improve teaching.

\section{Conclusion}

The practice teaching design of property valuation fit cognitive level and learning ability of student who major in real estate business and professional assessment in vocational college, and 
recognized by senior real estate appraiser. Teaching practice has proved that this teaching design implementation can make the students better to grasp basic vocational theory and skills of real estate assessor. That has the ability to qualify for real estate assessor and realize the goal of teaching. Students which to employ for the vocational real estate assessor after graduation, work ability have been appreciated in the property valuation institutions.

\section{References}

1. Vocational education and adult education department under the ministry of education. Teaching standard of vocational colleges (trial) [S]. 2013-02 / 2015-01-29.

2. Teaching civil engineering steering committee estate professional steering committee of higher vocational education. management and valuation professional teaching basic requirements of the higher vocational education [S]. 2012-12 / 2015-01-29.

3. The construction ministry of the People's Republic of China No. 97. Management regulations of city real estate intermediary services[Z]. 2001-08-15 / 2015-01-29.

4. GB/T 50291-1999.Appraisal code of real estate [S]. 1999-02-12 / 2015-01-29.

5. GB/T 18508-2001.Urban land appraisal regulation [S].2001-11-12 / 2015-01-29.

6. The construction ministry of the People's Republic of China No.151. The regulation of registered real estate appraiser [Z]. 2007-03-01 / 2015-01-29.

7. Ministry of Land and Resources of People's Republic of China No.35. Regulation of land valuer qualifying examination [Z]. 2006-11-22 / 2015-01-29.

8. Li Kecheng, Han Yuqi. Prepare for the case analysis seminar of Industry experts outside school. Chinese Worker Education 2014, (12)/: 156-157. 2014-12-25 / 2015-01-29. 